\title{
Evaluación de la fisibilidad y durabilidad de pizarras de techar mediante microscopía óptica y SEM
}

\section{Optical microscope and SEM evaluation of roofing slate fissility and durability}

\author{
F. Gómez-Fernández ${ }^{(*)}$, M. A. Castaño(**), B. Bauluz(***) y C. R. Ward(****)
}

Recepción/Received: 17-VII-08

Aceptación/Accepted: 17-XI-08

Publicado online/Online publishing: 20-XI-09

\section{RESUMEN}

Para evaluar la fisibilidad y la durabilidad de pizarras de techar comerciales, muestras representativas de diez yacimientos del NO de España han sido estudiadas mediante microscopía óptica de luz transmitida y reflejada, microscopía electrónica de barrido y ensayos tecnológicos.

Los sulfuros dominantes en las diferentes pizarras estudiadas son pirita o pirrotina, por lo que la alterabilidad de estas es muy variable. La especie carbonatada dominante es ankerita, lo que explica la baja reactividad de estas pizarras en medios ácidos. El espesor comercial mínimo varía en función de la microtextura de la roca, oscilando entre 3,5 y $5 \mathrm{~mm}$.

Se propone el uso de la metodología desarrollada en este trabajo, con objeto de eliminar la subjetividad de los inputs de entrada utilizados en las metodologías actuales de evaluación y modelización de yacimientos, lo que incidiría en la mejora de los rendimientos de las explotaciones y en la minimización de la producción de estériles.

Palabras clave: Rocas ornamentales, Petrografía, Microscopía Electrónica de Barrido (MEB), Durabilidad, Modelización.

\section{SUMMARY}

The fissility and durability of representative samples of commercial roofing slates from ten deposits in the NW of Spain have been evaluated using transmitted and reflectedlight optical microscopy, scanning electron microscopy, chemical testing and geomechanical procedures.

The dominant sulphides in the different slate samples are pyrite and pyrrhotite, the weathering potential of which can be highly variable. The dominant carbonate mineral is ankerite, which explains the low reactivity of these slates in acidic media. The minimum commercial plate thickness varies between 3.5 and $5 \mathrm{~mm}$, depending on the microtexture of the rock.

The methodology used in this paper is proposed in order to eliminate the subjectivity of input data that are used in current methods of evaluation and modelling of slate deposits, thus producing an improvement in the profitability of mining operations and a reduction in waste materials.

Keywords: Ornamental stones, Petrography, Scanning Electron Microscopy (SEM), Durability, Modelization.

\footnotetext{
(*) Universidad de León (León, España).

(**) Cupa Group. (Orense, España).

(***) Universidad de Zaragoza (Zaragoza, España).

(****) University of New South Wales (Sydney, Australia).
} 


\section{INTRODUCCIÓN}

La pizarra es una roca común, producto de metamorfismo de bajo grado, distinguida por la presencia de una esquistosidad penetrativa, denominada slaty cleavage. Las pizarras de techar son rocas de grano muy fino, caracterizadas por una alta fisibilidad debida a la orientación preferencial de los filosilicatos, la cual está condicionada por el tamaño de los elementos no planares y por la homogeneidad textural de la roca (1-4). Las mejores pizarras de techar tienen índices de cristalinidad de la illita $(5,6)$ entre 0,15 y $0,25^{\circ} 2 \theta$, lo que indica condiciones metamórficas de facies de esquistos verdes $(7,8)$.

España es el principal productor de pizarras de techar del mundo, con 114 plantas y más de 6.100 empleados. La producción de pizarra se ha venido incrementando desde los años cincuenta hasta alcanzar en la actualidad las 847.000 toneladas de pizarra manufacturada/año (9), con una facturación próxima a 400 M€/año.

La producción de pizarra en el NO de España genera ingentes volúmenes de estériles, con un elevadísimo impacto ambiental derivado. Diversas líneas de investigación que vienen desarrollándose con objeto de minimizar el impacto ambiental de estas explotaciones, en base a la aplicación de diversas metodologías para la recuperación de escombreras (10-12), el reciclado de escombros (13) y la inhibición de la oxidación de los sulfuros de hierro (14), hasta ahora no han obtenido resultados suficientemente satisfactorios. Quizá por ello es aún más importante el desarrollo de estrategias que minimicen la producción de estériles, como la implantación de minería de interior o la adecuada evaluación y planificación de las explotaciones (15-17). Un factor que interviene de forma relevante en la planificación y modelización de las explotaciones es la correcta estimación de la calidad de la pizarra $(18,19)$, tanto a escala de macizo rocoso como a escala de placa comercial (20).

\section{MARCO GEOLÓGICO}

En la parte occidental de la península Ibérica aflora un segmento del Orógeno Hercínico Europeo, denominado Macizo Ibérico, el cual ha sido dividido en diferentes dominios, que se agrupan en las siguientes cuatro zonas (21-24; Figura 1): Cantábrica, Asturoccidental-Leonesa (ZAOL), Centroibérica (ZCI) y Galicia-Tras Os Montes.

Los yacimientos de pizarras de techar se concentran en la ZCI, especialmente en el Dominio del Sinclinal de Truchas (distritos de Valdeorras y La Cabrera). También se encuentran numerosas canteras en la ZAOL (Dominios

\section{INTRODUCTION}

Slate is a common, widespread product of low-grade regional metamorphism, distinguished by a slaty cleavage. Roofing slates are very fine grained rocks, characterised by a high fissility due to a preferred orientation of the phyllosilicates, and conditioned by the size of the non-planar elements and by their textural homogeneity (1-4). The best roofing slates have illite crystallinity values $(5,6)$ of between 0.15 and $0.25^{\circ} 2 \theta$, which indicate a geological greenschist metamorphic facies $(7,8)$.

Spain is the largest producer of slates, with 114 factories and more than 6100 employees. Spanish production has increased since the 1950s and has now reached 847000 tonnes of manufactured slate/year (9), with invoicing close to $400 \mathrm{M} € /$ year.

The production of slate in NW Spain generates huge volumes of waste material that produce a very important environmental impact. Various investigations that have been carried out with the object of minimizing the environmental impact of these mining operations, based on the application of various methods for the recuperation of waste tailings (10-12), the recycling of waste (13) and the inhibition of iron sulphide oxidation, have not yet obtained satisfactory results (14). This makes it even more important to develop strategies that minimize waste production, such as the implementation of underground mining or adequate evaluation and planning of mining operations (15-17). An important and relevant factor in the planning and modelling of mining operations is the correct estimation of the quality of the slate $(18,19)$, both at the rock mass and slab scale (20).

\section{GEOLOGICAL SETTING}

In the NW of Spain, the Iberian Massif (a segment of the European Hercynian orogenic belt) has been divided into different domains, which are grouped in the following four Zones (21-24) (Figure 1): Cantabrian, West AsturLeonese (WALZ), Iberian Central (ICZ) and Galice-Tras Os Montes.

Spanish roofing slate deposits are concentrated in the ICZ, especially in the Truchas Syncline Domain (Valdeorras and La Cabrera districts). Numerous quarries are also found in the WALZ (Navia-Alto Sil, Mondoñedo 
de Navia-Alto Sil y Mondoñedo). La mayor parte de las pizarras explotadas son de edad ordovícica (Tabla 1), procedentes de las Formaciones Luarca, Casaio, Rozadais y Losadilla (25-27).

La Orogenia Hercínica en el Dominio del Sinclinal de Truchas de la ZCI y en la ZAOL fue un proceso deformativo polifásico con metamorfismo sincinemático asociado. Tanto en la ZCI como en la ZAOL se han diferenciado tres fases de deformación (28-31). La primera fase $\left(D_{1}\right)$, que es la mejor desarrollada, dio lugar a un gran número de pliegues de pequeña longitud de onda, con una esquistosidad de plano axial (slaty cleavage; $\mathrm{S}_{1}$ ) asociada, muy bien desarrollada, que constituye los planos de hienda en las pizarras de techar. Otras fases y episodios de deformación tardía generaron diversas estructuras que afectan negativamente a la calidad de las pizarras de techar, si bien afortunadamente estas estructuras están localizadas en áreas geográficas determinadas.

\section{METODOLOGÍA}

Se han recogido muestras representativas de diez yacimientos de pizarras de techar en los Dominios del Sinclinal de Truchas (ZCI) y Caurel-Peñalba y Navia-Alto Sil (ZAOL) (Figura 1; Tabla 1). and Caurel-Peñalba Domains). Most of the exploited slates are of Ordovician age (Table 1), drawn from the Luarca, Casaio, Rozadais and Losadilla Formations (2527).

The Hercynian Orogeny in the Truchas Syncline Domain of the ICZ and in the WALZ was a polyphasic deformative process associated with syn-kinematic metamorphism. Three deformative phases and late deformative episodes have been differentiated both in the ICZ and the WALZ (28-31). The first phase $\left(D_{1}\right)$, which is the best developed, generated a large number of folds with low wavelength and with an associated schistosity axial-plane (slaty cleavage; $S_{1}$ ) very well developed. This schistosity in the commercial slates appears as a slaty cleavage and constitutes the split planes. Other phases and late deformative episodes produced structures which adversely affect the roof slate quality, although fortunately these are present only in restricted areas.

\section{METHODOLOGY}

Representative samples from ten commercial roofing slate deposits were collected from the Truchas Syncline Domain of the ICZ, and from the Caurel-Peñalba and Navia-Alto Sil Domains of the WALZ (Figure 1) (Table 1).

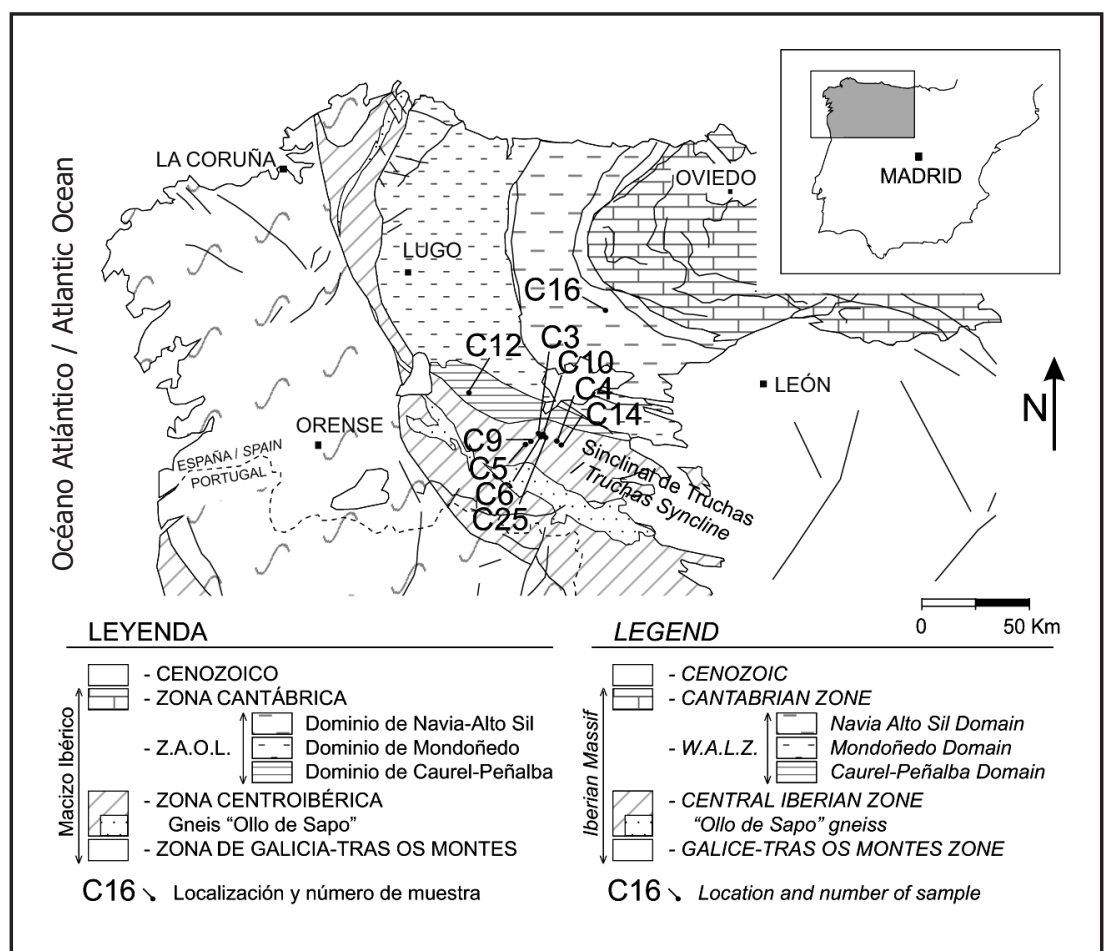

Figura 1. Ubicación de muestras y mapa geológico esquemático del NO de la Península Ibérica. Abreviaturas: Z.A.O.L. = Zona Asturoccidental-Leonesa.

Figure 1. Sample location and schematic geological map of the northwestern region of the Iberian Peninsula. Abbreviations: W.A.L.Z. = West Astur-Leonese Zone. 
Tabla 1 / Table 1

Localización de las muestras ensayadas. Location of samples tested.

\begin{tabular}{|c|c|c|c|c|}
\hline Muestra / Sample & $\begin{array}{l}\text { Zona geológica / } \\
\text { Geologic Zone }\end{array}$ & $\begin{array}{l}\text { Provincia geológica / } \\
\text { Geologic Province }\end{array}$ & Formación / Formation & Edad / Age \\
\hline $\mathrm{C} 3$ & ICZ & TS & Rozadais & UO \\
\hline $\mathrm{C4}$ & ICZ & TS & Rozadais & UO \\
\hline $\mathrm{C} 5$ & ICZ & TS & Losadilla & UO \\
\hline $\mathrm{C} 6$ & ICZ & TS & Rozadais & UO \\
\hline $\mathrm{C} 9$ & ICZ & TS & Casaio & UO \\
\hline $\mathrm{C} 10$ & ICZ & TS & Rozadais & UO \\
\hline $\mathrm{C} 12$ & WALZ & CPD & Luarca & MO \\
\hline C14 & ICZ & TS & Losadilla & UO \\
\hline $\mathrm{C} 16$ & WALZ & NASD & Luarca & LO-UO \\
\hline $\mathrm{C} 25$ & ICZ & TS & Rozadais & UO \\
\hline
\end{tabular}

Abreviaturas. ICZ $=$ Zona Centroibérica. WALZ $=$ Zona Asturoccidental-Leonesa. TS $=$ Sinclinal de Truchas. CPD $=$ Dominio de Caurel-Peñalba. NASD $=$ Dominio de Navia-Alto Sil. LO = Ordovícico Inferior. MO = Ordovícico Medio. UO = Ordovícico Superior. / Abbreviations. ICZ = Iberian Central Zone. WALZ = West Astur-Leonese Zone. TS = Truchas Syncline. CPD = Caurel-Peñalba Domain. NASD = Navia-Alto Sil Domain. LO = Lower Ordovician. MO = Middle Ordovician. UO = Upper Ordovician.

El volumen mayor de cada muestra fue sometido al proceso industrial de labrado en la planta de Cupire Padesa, S. A. (Grupo CUPA). Se generaron placas de pizarra lo más finas posible, con objeto de cuantificar el "espesor comercial mínimo", de acuerdo con el significado de este término que se ofrece en el apartado 7 de este artículo.

Otra parte de cada muestra de pizarra fue utilizada para determinar por calcimetría su contenido en carbonato, de acuerdo con la metodología establecida por la Norma Europea UNE-EN 12326-2:2000 (32).

Se realizaron láminas delgadas y láminas delgadas-pulidas de cada muestra, para estudios de microscopía óptica (luz transmitida y reflejada) y microscopía electrónica de barrido (SEM). El estudio de SEM fue realizado mediante un microscopio JEOL JSM-6100 dotado con detector D6679 de Oxford Instruments. Asimismo, se estudiaron láminas delgadas-pulidas de cada muestra utilizando una microsonda electrónica JEOL Superprobe JXA-8900M WDS. Las condiciones de medida fueron las siguientes: $15 \mathrm{kV}, 20 \mathrm{nA}$, diámetros de haz entre 1 y $5 \mu \mathrm{m}$ y un intervalo de conteo de $10 \mathrm{~s}$. Los patrones utilizados para la determinación de los elementos respectivos (mostrados entre paréntesis a continuación de cada uno de los patrones) fueron: Sillimanita ( $\mathrm{Al})$, albita-O ( $\mathrm{Na}, \mathrm{Si})$, almandino ( $\mathrm{Fe}, \mathrm{Mn})$, kaersutita ( $\mathrm{Ca}, \mathrm{Ti}, \mathrm{Mg})$, microclina $(\mathrm{K})$, apatito $15(\mathrm{~F}, \mathrm{Cl})$ y aleación $\mathrm{Hr}-160(\mathrm{Ni}, \mathrm{Cr})$.

La estimación del porcentaje de sulfuros de cada muestra fue realizada mediante microfotografía de luz reflejada y cálculo de superficies sobre lámina delgada pulida mediante Autocad 2000. Para convertir las superficies en porcentajes en peso, se asumió como densidad total de las muestras de pizarra $2,75 \mathrm{~g} / \mathrm{cm}^{3}$ y como densidades del conjunto de los sulfuros las siguientes: a) $5,01 \mathrm{~g} / \mathrm{cm}^{3}$
The greater part of each sample was submitted to the industrial processes of splitting in the plant of Cupire Padesa S. A. (CUPA Group). The thinnest slate plates possible were manufactured with the aim of quantifying the "minimum commercial thickness", in accordance with the definition of this term specified in part 7 of this article.

Another part of each slate sample was used for determination of carbonate content by calcimetry, according to the methodology set out in European Standard UNE-EN 12326-2:2000 (32).

Thin and polished thin sections of each sample were prepared for study by optical microscopy (transmitted and reflected light) and scanning electron microscopy (SEM). The SEM study was carried out using a JEOL JSM6100 fitted with an Oxford Instruments D6679 detector. Polished thin sections of each sample were also studied using a JEOL Superprobe JXA-8900M WDS electron microprobe. Measurement conditions were as follows: accelerating voltage $15 \mathrm{kV}$, beam current $20 \mathrm{nA}$, probe diameter between 1 and $5 \mu \mathrm{m}$ and a counting interval of 10 s. Sillimanite $(A l)$, albite-O $(\mathrm{Na}, \mathrm{Si})$, almandine ( $\mathrm{Fe}$, $\mathrm{Mn})$, kaersutite (Ca, $\mathrm{Ti}, \mathrm{Mg})$, microcline $(\mathrm{K})$, apatite-15 $(\mathrm{F}, \mathrm{Cl})$ and $\mathrm{Hr}-160$ alloy $(\mathrm{Ni}, \mathrm{Cr})$ were used respectively as standards for determination of the elements shown in brackets.

Evaluation of the sulphide mineral percentages in each sample was done from reflected light microphotographs and calculation of surface areas in polished thin sections using Autocad 2000. To convert the data to weight percentages a total density of $2.75 \mathrm{~g} / \mathrm{cm}^{3}$ was assumed for the slate samples; $5.01 \mathrm{~g} / \mathrm{cm}^{3}$ was taken as the density for all the sulphides in pyrite-rich 
para las muestras en las que el sulfuro dominante es pirita, y b) $4,61 \mathrm{~g} / \mathrm{cm}^{3}$ cuando el sulfuro dominante en la muestra es pirrotina.

\section{PETROGRAFÍA}

Los minerales esenciales en las muestras estudiadas son micas blancas (micas fengíticas), cuarzo, Fe-clorita (chamosita magnesiana) (33) y feldespato (albita). Los minerales accesorios varían en las distintas muestras, habiéndose encontrado ilmenita, rutilo, sulfuros (pirita, pirrotina, calcopirita, pentlandita, cobaltina, esfalerita, gersdorffita, galena y ullmannita), carbonatos (ankerita, siderita, calcita), grafito, monacita, apatito, circón y turmalina.

Las pizarras muestran una matriz de grano fino, formada esencialmente por minerales de hábito planar, en la que flotan elementos porfídicos, la mayor parte de las veces alargados paralelamente a la esquistosidad $\left(\mathrm{S}_{1}\right)$, con sombras de presión asociadas. La textura a escala microscópica varía según las muestras desde lepidoblástica a porfidoblástica (34) y solamente en algunas muestras se pueden diferenciar dominios con textura grano-lepidoblástica, que corresponden a intercalaciones de areniscas. En consecuencia, hemos clasificado las pizarras en tres grupos, de acuerdo con sus rasgos texturales:

- Tipo A (muestras C3, C4, C6, C10 y C25; Figuras 2A$2 \mathrm{~F})$. Pizarras de grano fino, con textura lepidoblástica dominante. A veces presentan intercalaciones arenosas (dominios con textura grano-lepidoblástica), generalmente continuas y de pequeña potencia, cortadas por la esquistosidad principal $\left(\mathrm{S}_{1}\right)$.

- Tipo B (muestras C5, C9, C14 y C16; Figuras 2I-2L). Pizarras de grano medio a grueso, con textura porfidoblástica. Presentan gran cantidad de elementos porfiroides de gran tamaño, aislados unos de otros, sin llegar a formar capas. La esquistosidad $\left(\mathrm{S}_{1}\right)$ bordea a estos elementos.

- Tipo C (muestra C12). Pizarras de grano medio a grueso, con textura porfidoblástica dominante (Figura 2G). Muestran dominios grano-lepidoblásticos (Figura $2 \mathrm{H}$ ), que se corresponden con intercalaciones arenosas relativamente potentes (hasta $0,9 \mathrm{~mm}$ ) y extensas (varios centímetros de extensión lateral).

\subsection{Matriz}

Está formada por minerales de grano muy fino (tamaño medio entre 4 y $10 \mu$; Figuras $3 \mathrm{~A}$ y B), fundamentalmente filosilicatos (mica blanca y clorita) y cantidades menores de cuarzo y feldespato. Otras fases minerales son sulfuros, grafito, ilmenita, rutilo, apatito y circón. La matriz muestra una fuerte orientación mineral, que define la esquistosidad de la roca $\left(\mathrm{S}_{1}\right)$. samples and $4.61 \mathrm{~g} / \mathrm{cm}^{3}$ for the sulphides in pyrrhotite rich-samples.

\section{PETROGRAPHY}

The major minerals in the samples are white mica (phengitic mica), quartz, Fe-chlorite (magnesian chamosite) (33) and feldspar (albite). Accessory minerals vary from sample to sample, and the following minerals have been detected: ilmenite, rutile, sulphides (pyrite, pyrrhotite, chalcopyrite, pentlandite, cobaltite, sphalerite, gersdorffite, galena and ullmannite), carbonates (ankerite, siderite, and calcite), graphite, monazite, apatite, zircon and tourmaline.

The slates have a fine-grained matrix, which is mainly composed of laminar minerals. Pressure shadows are developed in the matrix, and associated with porphyric elements that are usually elongated parallel to the slaty cleavage. The microscopic textures vary depending on the samples, and lepidoblastic to porphyroblastic textures have been described (34). Grano-lepidoblastic texture has been observed in some samples with bands of sand layers. Thus, three groups of slates have been distinguished with different textural features:

- Type A (samples C3, C4, C6, C10 and C25) (Figures $2 A-2 F)$. Fine grained slates with dominantly lepidoblastic textures. These also show some thin and continuous interbedded sandstone layers, which are grano-lepidoblastic texture domains. These domains are cut by an observable cleavage.

- Type B (samples C5, C9, C14 and C16) (Figures 2I2L). Medium to coarse grained slates with porphyroblastic textures. These slates display high proportions of large-size porphyric elements, which are isolated from each other and do not constitute layers. The slaty cleavage borders these elements.

- Type C (sample C12). Medium to coarse grained slates with dominant porphyroblastic textures (Figure 2G). They show grano-lepidoblastic domains (Figure $2 \mathrm{H})$, which correspond to interbedded sandstone layers; the latter are relatively thick (up to $0.9 \mathrm{~mm}$ ) and have lengths of several centimetres.

\subsection{Matrix}

The matrix has a very fine-size grain (average between 4 and $10 \mu \mathrm{m}$; Figures $3 A$ and $B$ ). The minerals are mostly phyllosilicates, such as white mica and chlorite, along with minor proportions of quartz and feldspar. Other phases are sulphides, graphite, ilmenite, rutile, apatite and zircon. The matrix is well orientated and this produces the cleavage of the rocks $\left(S_{1}\right)$. 


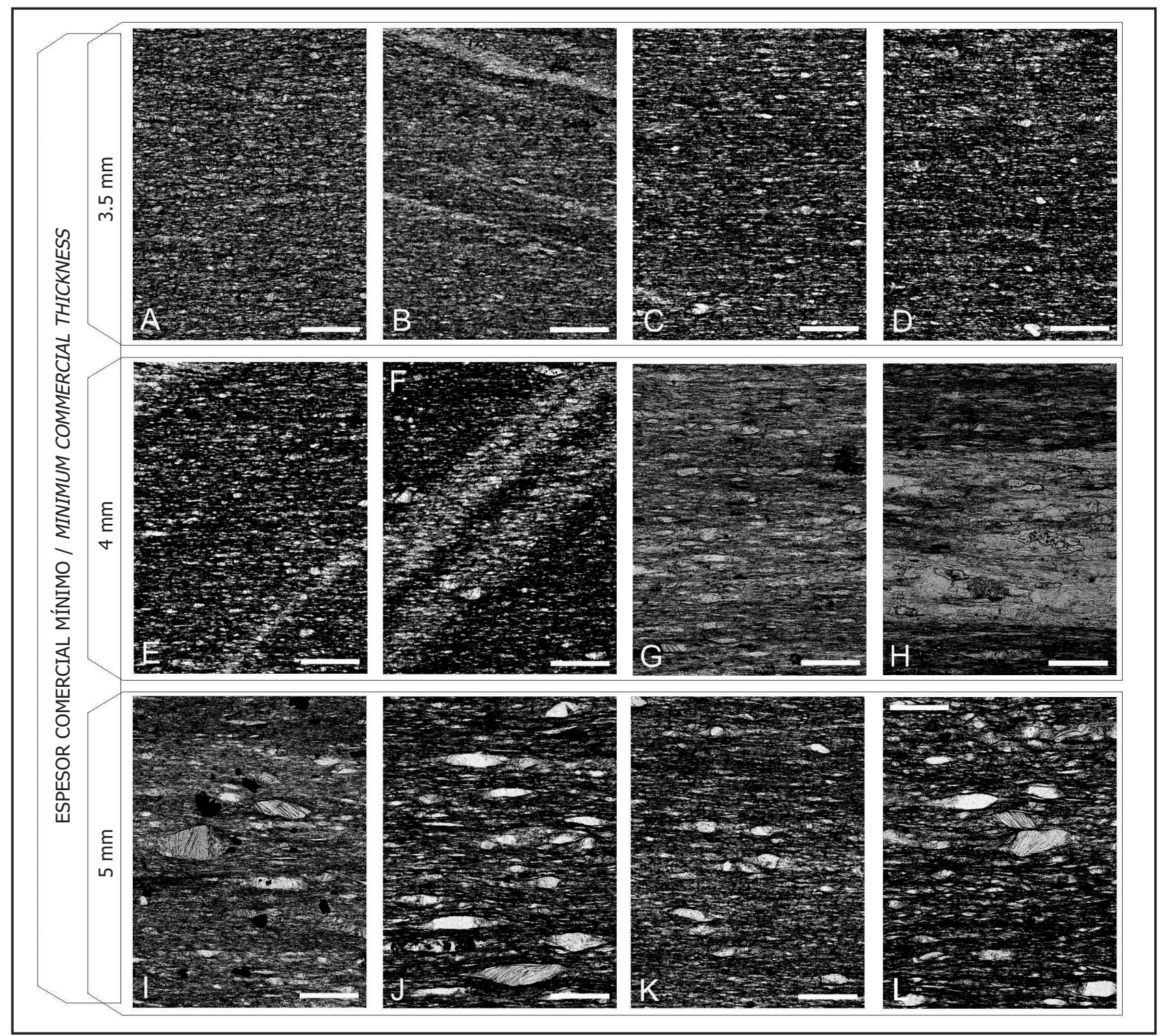

Figura 2. Microtextura de las pizarras y espesor comercial mínimo (microscopía óptica de luz transmitida; nícoles paralelos). Barra de escala $=250 \mu \mathrm{m}$. A) , C) y D): Textura lepidoblástica. B), E) y F): Textura lepidoblástica con dominios grano-lepidoblásticos, que corresponden a niveles de areniscas. G) y H): Texturas porfidoblásticas con elementos porfídicos de tamaño medio y un dominio grano-lepidoblástico interestratificado (zona central de H). I), J), K) y L): Textura porfidoblástica con elementos porfídicos de tamaño grueso. Las microfotografías $\mathrm{A}(\mathrm{C} 3), \mathrm{B}(\mathrm{C} 4), \mathrm{C}(\mathrm{C} 10), \mathrm{D}(\mathrm{C} 6), \mathrm{E}(\mathrm{C} 25), \mathrm{F}(\mathrm{C} 25), \mathrm{G}(\mathrm{C} 12), \mathrm{H}(\mathrm{C} 12), \mathrm{I}(\mathrm{C} 9), \mathrm{J}(\mathrm{C} 5), \mathrm{K}(\mathrm{C} 16), \mathrm{L}(\mathrm{C} 14)$ se corresponden con las muestras indicadas entre paréntesis.

Figure 2. Slate microtexture and minimum commercial thickness, based on transmitted-light optical microscopy using plane polarized light. Scale bar $=250 \mu \mathrm{m}$. A), C) and D): Lepidoblastic texture. B), E) and F): Lepidoblastic texture with grano-lepidoblastic domains which correspond to sand layers. G) and H): Porphyroblastic textures with medium size porphyric elements and a interlayered grano-lepidoblastic domain (central zone of $H) . I), J), K$ ) and $L$ ): Porphyroblastic texture with large porphyric elements.

Microphotographs $A(C 3), B(C 4), C(C 10), D(C 6), E(C 25), F(C 25), G(C 12), H(C 12), I(C 9), J(C 5), K(C 16), L(C 14)$ correspond to the samples indicated in brackets.

\subsection{Elementos porfídicos}

Las muestras estudiadas presentan elementos porfídicos de mineralogía diversa, fundamentalmente granos de cuarzo y feldespato, stacks de clorita-mica blanca (35), Figura $3 \mathrm{~A}$, carbonatos y elementos porfiroides ricos en sulfuros. Algunas pizarras pueden mostrar además

\subsection{Porphyric elements}

The samples have several different mineral phases acting as porphyric elements; these are typically quartz and feldspar, chlorite-white mica stacks (35), Figure 3A, carbonates, and sulphide-rich porphyric elements. Some slates may also have monazite, ilmenite and some 

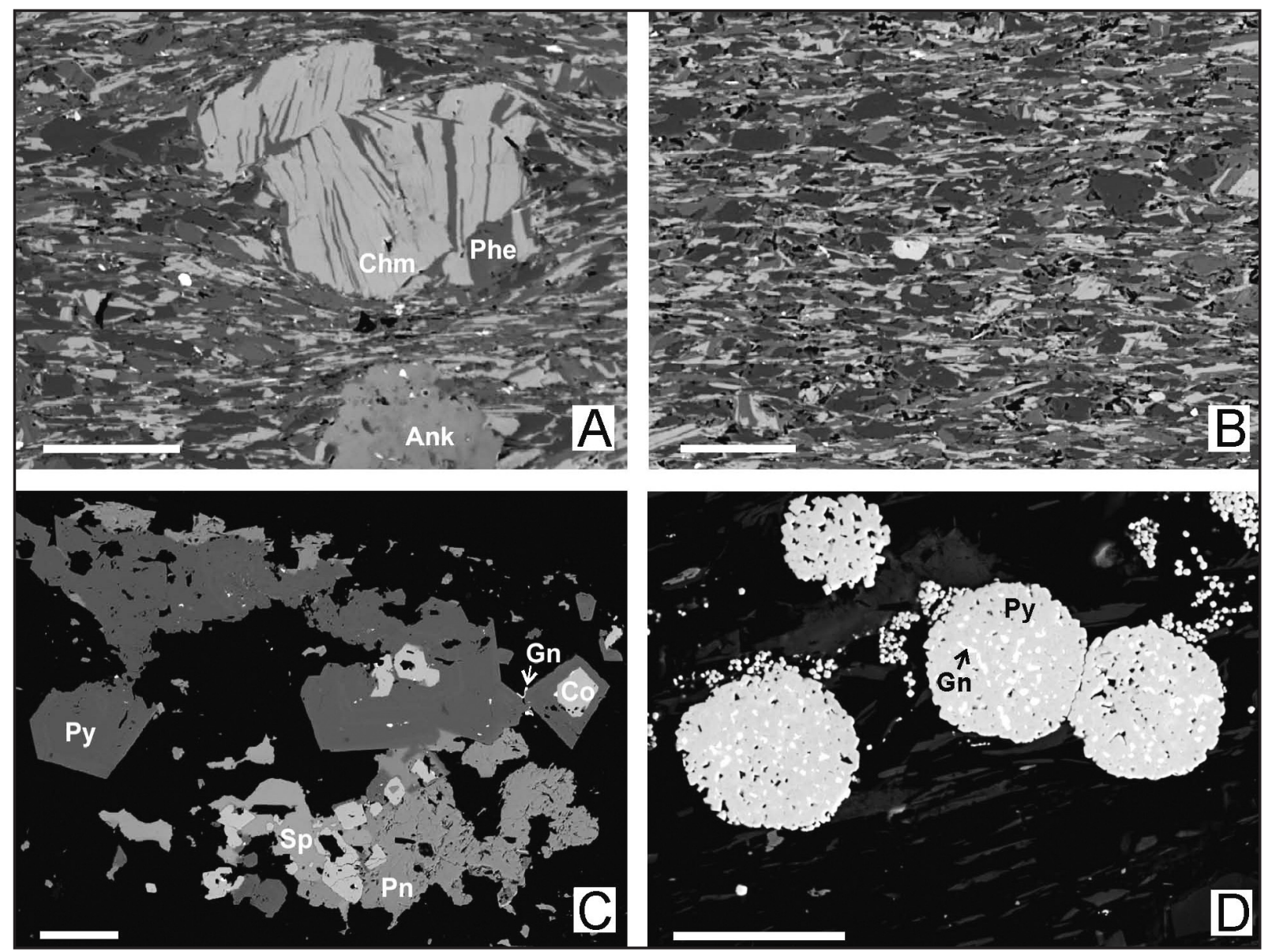

Figura 3. Imágenes de electrones retrodispersados mostrando elementos texturales de las pizarras. A) Elementos porfídicos (Stack de clorita-mica y grano de ankerita) con sombras de presión asociadas y bordeados por $\mathrm{S}_{1}$ (muestra C25); B) Pizarra de grano fino con textura lepidoblástica (C4); C) Sulfuros precinemáticos dentro de un agregado porfídico (C3); D) Pirita framboidal y galena tardías remplazando a la pizarra encajante $(\mathrm{C} 16)$. Barra de escala $=50 \mu \mathrm{m}$. $\mathrm{Py}=$ pirita; $\mathrm{Pn}=$ pentlandita; $\mathrm{Sp}=$ esfalerita; $\mathrm{Co}=\mathrm{cobaltina;}$ $\mathrm{Gn}$ = galena; Ank = ankerita; Phe = mica fengítica; $\mathrm{Chm}=$ chamosita.

Figure 3. BSE images showing textural elements of the slates. A) Porphyric elements (Stack of chlorite-mica and ankerite grain) with associated pressure shadows and bordered by $S_{1}$ (sample C25); B) Fine grained slate with lepidoblastic texture (C4); C) Pre-kinematic sulphides inside a porphyric aggregate (C3); D) Late phramboidal pyrite and galena replacing hosting slate (C16). Scale Bar $=50 \mu \mathrm{m}$. $P y=$ pyrite; $P n=$ pentlandite; $S p=$ sphalerite; $C o=$ cobaltite; $G n=$ galena; Ank = ankerite; Phe = phengitic mica; Chm = chamosite.

monacita, ilmenita y algunos granos de turmalina que destacan sobre el tamaño de la matriz. En el apartado siguiente se ofrece una descripción detallada de los elementos porfídicos formados total o parcialmente por sulfuros.

El tamaño medio de los distintos elementos porfídicos varía en las distintas muestras (desde $15 \times 30 \mu \mathrm{m}$ hasta $150 \times 400 \mu \mathrm{m})$, siendo especialmente importante su dimensión menor (medida perpendicularmente a $S_{1}$ ), ya que influye sobre el espesor comercial mínimo de las placas de pizarra.

La mayor parte de los minerales constituyentes de los elementos porfídicos son de origen sedimentario o diagenético temprano, habiendo sufrido transformaciones durante el metamorfismo. tourmaline grains of larger size than the other minerals in the matrix. A further description of those porphyric elements entirely or partially formed by sulphides is given in the following section.

The mean size of the porphyric elements varies from sample to sample (from $15 \times 30 \mu \mathrm{m}$ to $150 \times 400 \mu \mathrm{m}$ ). The lower dimension of these elements (measured perpendicular to $S_{1}$ ) is particularly important, since this value influences the minimum commercial thickness of the commercial plates formed from the slates.

Most of the minerals forming the porphyric elements are sedimentary or early diagenetic in origin that have undergone metamorphic transformation. 


\section{SULFUROS}

La proporción de sulfuros en las muestras, de acuerdo con los datos de microscopía óptica de luz reflejada, es relativamente baja, variando desde 0,06 a 0,76\% (Tabla 2). La pirita es el sulfuro dominante en la mayor parte de las muestras (C3, C4, C5, C6, C10, C14, C16 y $\mathrm{C} 25$ ). No obstante, la pirrotina es el sulfuro dominante en las pizarras C9 y $\mathrm{C} 12$ (Tabla 2).

Se han reconocido nueve sulfuros diferentes, lo que supone una diversidad mineralógica mayor que la descrita hasta ahora en pizarras de techar. Su mineralogía y relación con el encajante permite clasificarlos en dos tipologías diferentes:

- Sulfuros precinemáticos (Tipo I). Aparecen formando parte de agregados porfiroides junto a carbonatos y cuarzo $y$, en ocasiones grafito y filosilicatos. Su dimensión menor puede llegar a alcanzar $500 \mu \mathrm{m}$. Los sulfuros presentes son (Tabla 2): pirita, pirrotina, pentlandita, cobaltina, calcopirita, esfalerita, galena, ullmannita y gersdorffita. En la mayor parte de las muestras la pirita es el sulfuro precinemático dominante, excepto en las muestras C5, C12 y C16 en las que domina la pirrotina. Los sulfuros del Tipo I están presentes en todas las pizarras estudiadas.

- Sulfuros postcinemáticos (Tipo II). Aparecen cortando la $S_{1}$, lo que pone de manifiesto su carácter postcinemático. Se trata casi exclusivamente de pirita

\section{SULPHIDES}

The proportion of sulphide minerals, as determined by reflected-light optical microscopy, is relatively low, ranging from 0.06 to $0.76 \%$ (Table 2). Pyrite is seen to be the main sulphide mineral in most of the samples (C3, C4, C5, C6, C10, C14, C16 and C25). The main sulphide in slates C9 and C12, however, is pyrrhotite (Table 2).

Nine different types of sulphide minerals have been described in the slates studied. This represents a larger mineral variety than that usually described for roofing slates in the literature. The sulphide minerals and their relation with the host material permit them to be classified into two different categories:

- Pre-kinematic sulphides (Type I). These form porphyric aggregates along with carbonates and quartz, and sporadically with graphite and phyllosilicates. Their lower dimension may reach up to $500 \mu \mathrm{m}$. The sulphides in Type I occurrences (Table 2) are: pyrite, pyrrhotite, pentlandite, cobaltite, chalcopyrite, sphalerite, galena, ullmannite and gersdorffite. Pyrite is the dominant pre-kinematic sulphide in most of the samples (Figure 3C), except for samples C5, C12 and C16, in which pyrrhotite is the most abundant. Type I sulphides are present in all of the slates studied.

- Post-kinematic sulphides (Type II). The cleavage $S_{1}$ is cut by these sulphides, reflecting their post-kinematic origin. Pyrite is almost the only sulphide

Tabla 2 / Table 2

Mineralogía y distribución de sulfuros y carbonatos en las pizarras estudiadas.

Mineralogy and distribution of sulphides and carbonates in slates studied.

\begin{tabular}{|c|c|c|c|c|c|c|}
\hline \multirow{3}{*}{ Muestra / Sample } & \multicolumn{4}{|c|}{ Sulfuros / Sulphides } & \multicolumn{2}{|c|}{ Carbonatos / Carbonates } \\
\hline & \multirow{2}{*}{$\begin{array}{c}\left(^{*}\right) \\
\% \text { en peso / } \\
\text { Weight } \%\end{array}$} & \multicolumn{3}{|c|}{$(* * *)$ Mineralogía / Mineralogy } & \multirow{2}{*}{$\begin{array}{c}(* *) \\
\% \text { en peso / } \\
\text { Weight } \%\end{array}$} & \multirow{2}{*}{$\begin{array}{c}(* * *) \\
\text { Mineralogía } \\
\text { Mineralogy }\end{array}$} \\
\hline & & D & Tipo I / Type I & Tipo II / Type II & & \\
\hline $\mathrm{C3}$ & 0.27 & Py & $\mathrm{Py}, \mathrm{Pn},(\mathrm{Co}, \mathrm{Ccp}, \mathrm{Sp}, \mathrm{Gn}, \mathrm{Ul})$ & Py (Gn) & 0.50 & Ank \\
\hline C4 & 0.06 & Py & Py, (Sp, Ccp, Pn, Gn) & Py & 0.67 & Ank \\
\hline $\mathrm{C} 5$ & 0.27 & Py & Po, Py, Ccp (Pn, Sp, Co, Gn) & Py & 1.61 & Cal, Ank \\
\hline C6 & 0.22 & Py & Py, Ccp, Pn, (Ul, Gdf, Sp, Gn) & Py (Ccp) & 0.67 & Ank \\
\hline C9 & 0.46 & Po & Po, Sp, (Co, Ccp) & & 0.67 & Cal \\
\hline $\mathrm{C} 10$ & 0.12 & Py & Py, Co, (Ccp, Ul, Pn, Gn) & Py & 0.67 & Sd, Ank \\
\hline $\mathrm{C} 12$ & 0.33 & Po & Po, Py, (Co, Ccp) & Py & 0.67 & Ank \\
\hline C14 & 0.05 & Py & Py, Sp, Ccp (Pn, Gn) & Py $(G n)$ & 0.50 & Cal, Ank \\
\hline $\mathrm{C} 16$ & 0.76 & Py & Po, Py, Co, Ccp, Sp & Py (Gn) & 0.83 & Ank, Sd \\
\hline $\mathrm{C} 25$ & 0.06 & Py & $\mathrm{Py}, \mathrm{Pn}, \mathrm{Co}, \mathrm{Ccp},(\mathrm{Sp}, \mathrm{Gn})$ & & 0.83 & Cal, Ank \\
\hline
\end{tabular}

$\left(^{*}\right)$ Determinado sobre microfotografías por cálculo de superficies. Microscopía de luz reflejada sobre láminas delgadas pulidas. / Determined by surface area calculations from reflected light microphotographs of polished thin sections.

(**) Determinado por calcimetría (EN 12326-2) (32). / Determined by calcimetry (EN 12326-2) (32).

$(* * *)$ Determinado por microscopía óptica, SEM y EMPA. Abreviaturas: D = sulfuro dominante; Ank = ankerita; Cal = calcita; Ccp = calcopirita; Gn = galena; $\mathrm{Pn}=$ pentlandita; $\mathrm{Po}=$ pirrotina; $\mathrm{Py}=$ pirita; $\mathrm{Sd}=$ siderita; $\mathrm{Sp}=$ esfalerita; $\mathrm{Co}=$ cobaltina; Ul = ullmannita; Gdf = gersdorffita. Los sulfuros minoritarios aparecen entre paréntesis. / Determined by optical microscopy, SEM and EMPA. Abbreviations: $D=d o m i n a n t ~ s u l p h i d e ; ~ A n k=$ ankerite; Cal = calcite; $C c p=$ chalcopyrite; $G n=$ galena; $P n=$ pentlandite; $P o=$ pyrrhotite; $P y=$ pyrite; $S d=$ siderite; $S p=$ sphalerite; Co = cobaltite; UI = ullmannite; Gdf = gersdorffite. Minor sulphides are between brackets. 
(Tabla 2), con galena y calcopirita muy ocasionales y escasas (Figura 3D).

\section{CARBONATOS}

La ankerita y la calcita aparecen como fases detríticas y formando elementos porfídicos junto con sulfuros y cuarzo. En aureolas de alteración de sulfuros se ha identificado asimismo siderita. La muestra C14 también muestra venas de calcita tardías.

\subsection{Microanálisis}

Se han realizado setenta y seis microanálisis de carbonatos mediante microsonda electrónica. Los datos proceden de todas las pizarras estudiadas (Tabla 3 ) y han sido normalizados con respecto a $(\mathrm{Mg}+\mathrm{Ca}+\mathrm{Mn}+\mathrm{Fe})$ at $=100$.

La ankerita es el carbonato más común, estando presente en nueve de las diez muestras estudiadas (Tabla 2). Presenta una composición homogénea en todas ellas, con la siguiente fórmula estructural promedio: $\left(\mathrm{Mg}_{0.23}, \mathrm{Ca}_{0.51}\right.$, $\left.\mathrm{Mn}_{0.05}, \mathrm{Fe}_{0.20}\right) \mathrm{CO}_{3}$. Otros carbonatos, tales como calcita de composición promedio $\left(\mathrm{Mg}_{0.01}, \mathrm{Ca}_{0.95}, \mathrm{Mn}_{0.02}, \mathrm{Fe}_{0.02}\right.$ ) $\mathrm{CO}_{3}$, y sideritas de composiciones variadas (Tabla 3), están presentes en un número de muestras significativamente menor.

\subsection{Determinación del contenido en carbonato}

De acuerdo con la Norma Europea UNE-EN 123262:2000 (32), el contenido en carbonato de las pizarras se expresa en $\% \mathrm{CaCO}_{3}$ equivalente. No obstante, el estudio microscópico muestra que el carbonato dominante en la mayor parte de las muestras es ankerita, estando presentes además calcita y siderita en algunas muestras. Los resultados del ensayo tecnológico (Tabla 2) indican que el contenido total en carbonato de las muestras varía entre 0,50 y $1,61 \% \mathrm{CaCO}_{3}$ equivalente. present in this type of occurrence (Table 2), although in some (uncommon) cases galena and chalcopyrite have been detected (Figure 3D).

\section{CARBONATES}

Ankerite and calcite appear to be present as detrital phases and form the porphyric elements with sulphides and quartz. Siderite has been identified in aureoles of sulphide weathering. Sample C14 also shows late-stage calcite veins.

\subsection{Microanalysis}

Seventy-six determinations of carbonate composition have been performed using the electron microprobe. The data come from all of the samples studied (Table 3), and have been normalized to $(\mathrm{Mg}+\mathrm{Ca}+\mathrm{Mn}+\mathrm{Fe})$ at $=100$.

Ankerite is the most common carbonate, and has been detected in nine of the ten samples (Table 2) studied. The ankerite shows a homogenous composition in all of the slates, with the following average formula: $\left(\mathrm{Mg}_{0.23}\right.$, $\mathrm{Ca}_{0.51}, \mathrm{Mn}_{0.05}, \mathrm{Fe}_{0.20} \mathrm{CO}_{3}$. Other carbonates have been found in a few samples, such as calcite with a mean composition of $\left(\mathrm{Mg}_{0.01}, \mathrm{Ca}_{0.95}, \mathrm{Mn}_{0.02}, \mathrm{Fe}_{0.02}\right) \mathrm{CO}_{3}$, and siderite with broad chemical variations (Table 3 ).

\subsection{Determination of carbonate content}

Under European Standard UNE-EN 12326-2:2000 (32) the carbonate content of slates is given in percent $\mathrm{CaCO}_{3}$ equivalent. However, the microscope study shows that the dominant carbonate in most of the slates is ankerite and that other carbonates present in many of the samples are calcite and siderite. The results (Table 2) indicate that the total carbonate content of the samples ranges from 0.50 to $1.61 \% \mathrm{CaCO}_{3}$ equivalent.

Tabla 3 / Table 3

Composición de carbonatos determinada por microsonda electrónica (en \%). Composition of carbonates as determined by electron microprobe (at \%).

\begin{tabular}{|c|c|c|c|c|c|c|c|}
\hline \multirow{4}{*}{$\begin{array}{c}\text { Mineral } \\
\text { Muestras / Samples } \\
\mathbf{N}=\end{array}$} & \multirow{3}{*}{\multicolumn{2}{|c|}{$\begin{array}{c}\text { Ankerita / Ankerite } \\
\left({ }^{*}\right) \\
40\end{array}$}} & \multirow{2}{*}{\multicolumn{2}{|c|}{$\begin{array}{l}\text { Calcita / Calcite } \\
\text { C5, C9, C14, C25 }\end{array}$}} & \multicolumn{3}{|c|}{ Siderita / Siderite } \\
\hline & & & & & \multicolumn{2}{|c|}{ C10 } & \multirow{3}{*}{$\begin{array}{c}\text { C16 } \\
4 \\
\text { at\% }\end{array}$} \\
\hline & & & & & \multirow{2}{*}{$\begin{array}{c}3 \\
\text { at\% }\end{array}$} & \multirow{2}{*}{$\begin{array}{c}2 \\
\text { at } \%\end{array}$} & \\
\hline & at\% & $\sigma$ & at\% & $\sigma$ & & & \\
\hline $\mathrm{Ca}$ & 51.48 & $(1.49)$ & 95.11 & $(3.04)$ & 0.65 & 0.95 & 12.19 \\
\hline $\mathrm{Mg}$ & 23.43 & $(3.32)$ & 1.12 & $(0.67)$ & 16.39 & 33.06 & 2.35 \\
\hline $\mathrm{Fe}$ & 20.27 & $(2.47)$ & 2.04 & $(1.25)$ & 74.68 & 56.58 & 63.20 \\
\hline $\mathrm{Mn}$ & 4.82 & (1.62) & 1.73 & $(1.14)$ & 8.28 & 9.41 & 22.26 \\
\hline
\end{tabular}

$(*)=\mathrm{C} 3, \mathrm{C} 4, \mathrm{C} 5, \mathrm{C} 6, \mathrm{C} 10, \mathrm{C} 12, \mathrm{C} 14, \mathrm{C} 16, \mathrm{C} 25$.

$\sigma=$ desviación estándar de los valores medios de cada muestra. / $\sigma=$ standard deviation of the average values. 


\section{ESPESOR COMERCIAL MÍNIMO}

Algunos autores (1-4) han indicado la existencia de una relación entre el grado de fisibilidad y la homogeneidad textural de las pizarras de techar, si bien hasta ahora no se ha mostrado la base sobre la que descansa tal afirmación. En el presente trabajo se precisa la afirmación anterior, sustituyendo el término "grado de fisibilidad", un tanto vago, por el término "espesor comercial mínimo" (E), de significado concreto y cuantificable. Definimos espesor comercial mínimo como el espesor mínimo y constante al que se pueden obtener placas de pizarra de forma sistemática y rentable a partir de un determinado macizo rocoso. Está determinado no solamente por la capacidad de la roca de ser labrada a un espesor determinado, sino también por la eficiencia económica del proceso de labrado, directamente relacionada con el tiempo empleado por el labrador en lograr una placa de ese espesor.

Según datos ofrecidos por el Grupo CUPA, el espesor comercial mínimo para las pizarras estudiadas, varía de la forma siguiente:

\section{MINIMUM COMMERCIAL THICKNESS}

Certain authors (1-4) have pointed out the existence of a relation between the fissility grade and the grain-size homogeneity of roofing slates, even though the basis upon which this relation depends has not yet been proved. Some of the relevant terminology has been clarified in this work, replacing the somewhat vague term "fissility grade" with the term "minimum commercial thickness" (E), and providing the latter term with a concrete and quantifiable meaning. The minimum commercial thickness is the minimum and constant thickness of plates of slate that can be obtained in a systematic and profitable form from a certain rocky mass. It is determined both by the capacity of the rock to be systematically split at a determined thickness and by the economic efficiency of the splitting process, which is directly related to the time used by the splitter to achieve a slate slab of the desired thickness.

According to data from the CUPA Group, the minimum commercial thickness for the samples studied varies in the following way:

$$
\mathrm{E}_{\mathrm{C} 14}=\mathrm{E}_{\mathrm{C} 5}=\mathrm{E}_{\mathrm{C} 16}=\mathrm{E}_{\mathrm{C} 9}=5 \mathrm{~mm}>\mathrm{E}_{\mathrm{C} 25}=\mathrm{E}_{\mathrm{C} 12}=4 \mathrm{~mm}>\mathrm{E}_{\mathrm{C} 3}=\mathrm{E}_{\mathrm{C} 4}=\mathrm{E}_{\mathrm{C} 6}=\mathrm{E}_{\mathrm{C} 10}=3,5 \mathrm{~mm}
$$

No hemos encontrado ninguna relación entre el espesor comercial mínimo y la mineralogía de las pizarras; sin embargo, el espesor comercial mínimo de las placas de pizarra está claramente relacionado con la microtextura de la roca (Figura 2). Las pizarras que permiten la realización de placas más delgadas son pizarras de grano fino con textura lepidoblástica, a veces con presencia de dominios arenosos, cortados por la esquistosidad $\left(\mathrm{S}_{1}\right)$. Por el contrario, las pizarras de textura porfidoblástica, con elementos porfídicos de gran tamaño, bordeados por la esquistosidad $\left(\mathrm{S}_{1}\right)$, no permiten la obtención de placas finas y se comercializan en placas de mayor grosor.

\section{DISCUSIÓN}

Desde hace algunos años se viene utilizando el concepto de "calidad de la pizarra" como equivalente al concepto de ley en minería metálica. La calidad de la pizarra viene determinada por diversos parámetros, tanto mecánicos como estéticos, considerados tanto a escala de macizo rocoso como a escala de placa comercial. La valoración de estos parámetros y su tratamiento estadístico en base a métodos estadísticos multivariantes (18) y redes bayesianas (20) ha permitido en los últimos años, por una parte, la evaluación de la calidad de la pizarra de techar $y$, por otra, el desarrollo de modelizaciones de yacimientos en base a técnicas geoestadísticas y sistemas de lógica difusa $(15-17,19)$. Sin embargo, estas técnicas tienen el inconveniente de que
We have not found any relationship between the minimum commercial thickness and the slate mineralogy; however, the minimum feasible thickness of commercial slate plates is clearly related to the rock microtexture (Figure 2). The slates that permit manufacture of thinner plates are fine grained slates with lepidoblastic texture and occasionally with sporadic sand domains that are cut by the cleavage $\left(S_{1}\right)$. In contrast, slates with porphyroblastic texture and large sized porphyric elements, which are bordered by the slaty cleavage $\left(S_{1}\right)$, do not permit the manufacture of thin plates and are sold as thicker plates.

\section{DISCUSSION}

The term "slate quality" has been in use for a number of years as an equivalent to the "ore grade" referred to in traditional extraction activities as metalliferous mining. Slate quality is determined by various parameters, as much mechanical as aesthetic, considered equally at a rock mass and a slab scale. The valuation of these parameters and their statistical usage with reference to multivariate statistical techniques (18) and Bayesian networks (20) over recent years has permitted both the evaluation of roofing slate and the modeling of mineable deposits, with the application of geostatistical techniques and fuzzy logic expert systems (15-17, 19). However, these techniques suffer the inconvenience that many of the quality parameters are evaluated by means of 
muchos de los parámetros de calidad son valorados en base a observaciones macroscópicas, realizadas por un experto en pizarra a partir de testigos de sondeo o en los bancos de la explotación. En consecuencia, la información de entrada en el sistema es frecuentemente subjetiva.

De acuerdo con lo que se muestra en apartados anteriores, las técnicas de microscopía óptica, SEM y ensayos tecnológicos, permiten determinar la concentración y caracterizar la mineralogía de sulfuros y carbonatos, así como la microtextura de la roca, variables que están directamente relacionadas con la durabilidad y la fisibilidad de la pizarra.

La relación existente entre microtextura y fisibilidad se ha puesto de manifiesto en el apartado anterior. La fisibilidad es un aspecto importante a valorar, ya que el espesor comercial mínimo incide directamente en el rendimiento económico de una explotación, dado que a igualdad de condiciones restantes, el rendimiento económico de una explotación está relacionado inversamente con el espesor comercial mínimo.

La durabilidad de la pizarra está condicionada entre otros factores por la concentración y especialmente por la naturaleza de los sulfuros y carbonatos contenidos en ella.

Por lo que respecta a los sulfuros, la pirrotina es mucho más fácilmente alterable en condiciones ambientales que otros sulfuros de hierro como pirita o calcopirita (36-39). Sin embrago, aunque parece claro que el mayor problema para la durabilidad de la pizarra lo representan los sulfuros de hierro, el papel que pueden jugar sulfuros minoritarios, como los identificados en este trabajo (pentlandita, gersdorffita, ullmannita, etc.), en los procesos de alteración aún no ha sido investigado.

En cuanto a los carbonatos, la alterabilidad viene condicionada por su mineralogía, la concentración y la disposición textural de los elementos carbonatados. La calcita es mucho más fácilmente alterable en condiciones ambientales que otros carbonatos como dolomita, ankerita o siderita $(40,41)$. Por otra parte, las alteraciones de elementos planares continuos, como por ejemplo venas carbonatadas, pueden dañar a la pizarra en mucho mayor grado que la alteración de elementos carbonatados aislados, como por ejemplo granos detríticos.

Todo lo anterior pone de manifiesto que, en el proceso de evaluación de la calidad de la pizarra, su caracterización textural, así como la cuantificación y la determinación de las diferentes especies de sulfuros y carbonatos, pueden generar inputs de entrada con un grado de incertidumbre muy inferior a los generados actualmente macroscopic observations, carried out by a slate expert on continuous borehole samples or material in the extraction banks. Consequently the nature of the input information is often subjective.

Optical microscopy and SEM techniques, combined with other test procedures, permit more objective characterization, including determination of parameters such as sulphide and carbonate mineralogy as well as the microtexture of the rock, both of which are directly related to slate fissility and durability.

The actual relationship between microtexture and fissility has been demonstrated above. Fissility is an important aspect to be evaluated since the minimum commercial thickness has a direct inverse effect on the profitability of a mining area under otherwise similar conditions.

The durability of the slate is conditioned, among other factors, by the concentration and especially the nature of the sulphides and carbonates contained therein.

With regards to the sulphides, pyrrhotite is much more easily weathered in atmospheric conditions than other iron sulphides such as pyrite or chalcopyrite (36-39). However, although it appears clear that iron sulphides represent the biggest problem for slate durability, the effect that minor sulphides, such as those identified in this work (pentlandite, gersdorffite, ullmanite, etc.), can have in the weathering processes has not yet been investigated.

The potential weathering of slate is also conditioned by the mineralogy, concentration and textural disposition of the carbonate minerals. Calcite is much more easily weathered in atmospheric conditions than other carbonates such as dolomite, ankerite or siderite (40, 41). Furthermore, weathering of continuous planar elements, such as for example carbonate veins, can damage the slate much more than weathering of isolated carbonate elements, such as for example discrete carbonate grains.

All of the above demonstrate that, in the process of slate quality evaluation, textural characterization and quantitative determination of the different types of sulphide and carbonate minerals can generate input data with a degree of uncertainty much lower than that currently produced by direct macroscopic observation, 
por observación macroscópica directa, con lo que la evaluación de la calidad de la pizarra resultante, así como las evaluaciones y modelizaciones de yacimientos derivadas de ésta, estarían más próximas a la realidad.

En estudios previos (42) se han hecho sugerencias que van en la misma dirección a la indicada aquí. Concretamente, se ha propuesto evaluar la oxidabilidad de los sulfuros presentes en placas de pizarra en base a estudios con microsonda electrónica, ataque con $\mathrm{H}_{2} \mathrm{O}_{2}$ y fotografía digital, como alternativa al ensayo EN-123262 (32) de ciclo térmico.

\section{CONCLUSIONES}

Se han estudiado los rasgos petrográficos y mineralógicos de muestras representativas de diez yacimientos españoles de pizarras para cubiertas. Las conclusiones obtenidas son las siguientes:

- Se ha puesto en evidencia con carácter general la existencia de dos fases de precipitación de sulfuros:

a) Una fase precinemática, representada por elementos porfídicos ricos en sulfuros, entre los que se han identificado pirita, pirrotina, pentlandita, cobaltina, calcopirita, esfalerita, galena, ullmannita y gersdorffita.

b) Una fase postcinemática, representada por la deposición muy mayoritaria de pirita.

- Pirita y pirrotina son los sulfuros dominantes en las muestras estudiadas. La diversidad de los sulfuros minoritarios identificados es superior a la descrita hasta ahora en la literatura geológica sobre pizarras de techar. Si bien se ignora el papel que pueden jugar sulfuros minoritarios (por ejemplo, gersdorffita, ullmannita) en los procesos de oxidación en condiciones ambientales, parece claro que el mayor problema lo representan los sulfuros de hierro, con tasas de oxidación de la pirrotina muy superiores a las de la pirita y calcopirita.

- La ankerita, de fórmula estructural promedio ( $\mathrm{Mg}_{0.23 \text {, }}$ $\left.\mathrm{Ca}_{0.51}, \mathrm{Mn}_{0.05}, \mathrm{Fe}_{0.20}\right) \mathrm{CO}_{3}$, es el carbonato dominante en la mayor parte de las pizarras estudiadas. Otros carbonatos presentes en algunas muestras son calcita, de fórmula estructural $\left(\mathrm{Mg}_{0.01}, \mathrm{Ca}_{0.95}, \mathrm{Mn}_{0.02}\right.$, $\left.\mathrm{Fe}_{0.02}\right) \mathrm{CO}_{3}$ y siderita. El hecho de que la ankerita aparezca como granos detríticos aislados y el que la alterabilidad de este mineral en condiciones ambientales sea significativamente inferior a la de la calcita minimiza en gran medida los riesgos de alteración de las pizarras estudiadas.

- Las pizarras de techar de bajo espesor comercial mínimo, que permiten la obtención de placas allowing evaluation of slate quality, as well as the evaluation and modeling of slate deposits derived from such quality data, to be much closer to reality.

Previous studies (42) have made suggestions that point to similar methodology. To be more specific, the evaluation of the oxidability of the sulphides present in the slabs has been proposed, based on studies with electron microprobe, $\mathrm{H}_{2} \mathrm{O}_{2}$ attack and digital photography, as an alternative to the EN-12326-2 (32) thermal cycle test.

\section{CONCLUSIONS}

The mineralogical and petrographic features of representative samples of ten Spanish deposits of commercial roofing slates have been studied. The following conclusions have been drawn:

- Two phases of sulphide precipitation have taken place and affected the slate deposits:

a) A pre-kinematic phase, represented by sulphide-rich porphyric elements in which pyrite, pyrrhotite, pentlandite, cobaltite, chalcopyrite, sphalerite, galena, ullmannite and gersdorffite have been identified.

b) A post-kinematic phase, in which pyrite was almost the only sulphide deposited.

- Pyrite and pyrrhotite are the dominant sulphide minerals. The diversity of the minor sulphides identified is greater than that previously recognized in the geological literature on roofing slate. Notwithstanding the impact that the minor sulphides (such as gersdorffite or ullmanite) can have on oxidation processes in atmospheric conditions, it seems clear that the iron sulphides represent the biggest problem, with pyrrhotite oxidation rates being much higher than those of pyrite and chalcopyrite.

- Ankerite, with an average structural formula

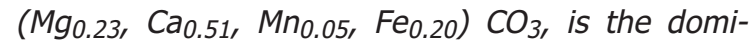
nant carbonate mineral in most of the slates studied. Other carbonates present in certain samples are calcite, with a structural formula (Mgo.01, $\mathrm{Ca}_{0.95}, \mathrm{Mn}_{0.02}, \mathrm{Fe}_{0.02} \mathrm{CO}_{3}$, and siderite. The fact that ankerite appears as isolated grains and that the rate of ankerite weathering in atmospheric conditions is significantly lower than that of calcite minimize to a great extent the weathering risks in the slate samples studied.

- Roofing slates with a low minimum commercial thickness, allowing production of thin commercial slate 
comerciales finas, son pizarras de grano fino con microtexturas lepidoblásticas, a veces con algunas intercalaciones de dominios arenosos de microtextura grano-lepidoblástica. Por el contrario, las pizarras de elevado espesor comercial mínimo, de las que solamente se pueden obtener placas comerciales gruesas, muestran microtexturas porfidobásticas.

- En el proceso de evaluación de la calidad de la pizarra en base a métodos estadísticos multivariantes o redes bayesianas, proponemos que la valoración de los inputs de entrada relativos a su fisibilidad y su durabilidad se realice en base a estudios de microscopía óptica, SEM y ensayos tecnológicos, en lugar de las valoraciones a escala macroscópica que se vienen realizando en la actualidad por expertos en pizarra. De esta manera se eliminarán subjetividades de los inputs de entrada utilizados en los procesos de evaluación y modelización de yacimientos y, en consecuencia, se propiciará la obtención de resultados más próximos a la realidad, mejorando los rendimientos de la explotación y evitando la apertura de bancos no rentables y en consecuencia la excesiva producción de estériles.

\section{AGRADECIMIENTOS}

Los autores desean mostrar su agradecimiento al director y al equipo técnico del Grupo CUPA, por autorizar y colaborar con el desarrollo de este estudio. plates, are slates with a fine grain size and a lepidoblastic microtexture, sometimes containing sandy bands with a grano-lepidoblastic microtexture. On the other hand, slates with a high minimum commercial thickness, from which only thicker commercial plates can be obtained, show porphyroblastic microtextures.

- As part of a process for evaluating slate quality by means of multivariate statistical techniques or Bayesian networks, we propose that the objective input data related to fissility and durability be based upon optical microscope and SEM studies, together with mineralogical and chemical test procedures, instead of the macroscopic scale evaluations carried out by slate experts that are currently in use. By doing so, subjectivity in the input data used to evaluate and model slate deposits for mining will be eliminated and results obtained that are closer to reality. This will improve the profitability of mining operations and avoiding the opening of uneconomic benches and, as a consequence, reduce excessive waste production.

\section{ACKNOWLEDGMENTS}

The authors are very grateful to the manager and technical group of the Cupa Group, for authorizing and collaborating with the development of this study.

\section{BIBLIOGRAFÍA / BIBLIOGRAPHY}

(1) Barros, J. C.; Castaño, M.; Hacar, M.; Lombardero, M.; Del Olmo Sanz, A.: "Metodología de investigación de los yacimientos de pizarras para cubiertas", Cuad. Lab. Xeol. Laxe, vol. 10 (1985), pp. 429-444.

(2) Lombardero, M.: "Las pizarras ornamentales", Roc Máquina, vol. 3 (1988), pp. 14-27.

(3) Lombardero, M.; García-Guinea, J.; Cárdenes, V.: "The geology of roofing slate", Industrial Minerals and Extractive Industry Geology, Geological Society Special Publication (2002), pp. 59-66.

(4) Lombardero, M.: "Caracterización de las pizarras para cubiertas mediante técnicas petrográficas", Canteras y Explotaciones, vol. 325 (1994), pp. 75-81.

(5) Kubler, B.: "Evaluation quantitative du metamorphisme par la cristallinite de l'illite", Bull. Centre Rech. Pau-SNPA, vol. 2 (1968), pp. $385-397$.

(6) Weber, K.: "Notes on the determination of illite crystallinity", N. Jahrb. Mineral., vol. 6 (1972), pp. 267-276.

(7) García-Guinea, J.; Lombardero, M.; Roberts, B.; Taboada, J.; Peto, A.: "Mineralogy and microstructure of roofing slate: thermo-optical behaviour and fissility", Mater. Construcc., vol. 48, núm. 251 (1998), pp. 37-48.

(8) García-Guinea, J.; Cárdenes, V.; Correcher, V.; Delgado, A.; Lombardero, M.; Barros, J. C.: "Dehydroxylation and Ostwald ripening effects in roofing slates", Bol. Soc. Esp. Cerám. V., vol. 39, núm. 4 (2000), pp. 589-594.

(9) Federación Española de la Piedra Natural. Informe sobre la situación de Sector de la Piedra Natural en 2006. http://www.fdp.es, p. 47. (10) Garzón, E.; García, V. M.; González, F.; García, J. R.: "Método alternativo en el proceso de recuperación de escombreras de pizarra", Boletín del Instituto Tecnológico de la Pizarra, vol. 5 (2006), pp. 19-27.

(11) Santaolla, M. C.; Vidal, M.; Álvarez, A.; López Fabal, A.; Mezquita, F.; Seoane, S.: "Utilización de lodos de pizarra en la recuperación de escombreras (I). Caracterización", Tecnoambiente, vol. 68 (1997), pp. 67-70.

(12) Santaolla, M. C.; Vidal, M.; Álvarez, A.; Teijeiro, T.; López Fabal, A.; Seoane, S.; Mezquita, F.: "Utilización de lodos de pizarra en la recuperación de escombreras (II). Utilización como sustrato de vegetación", Tecnoambiente, vol. 69 (1997), pp. 60-63.

(13) Groba, M.; Llamas, B.: "Reutilización de materiales de escombrera de pizarra". Boletín del Instituto Tecnológico de la Pizarra, vol. 3 (2005), pp. 20-27. 
(14) Cárdenes, V.; García-Guinea, J.; Monterroso, C.; De la Horra, R.: "Protocol for assessing the effectiveness of protective coatings for roofing slate", Mater. Construc., vol. 58, núm. 289-290 (2008), pp. 263-279.

(15) Bastante, F. G.; Ordóñez, C.; Taboada, J.; Matías, J. M.: "Comparison of indicator kriging, conditional indicator simulation and multiple-point statistics used to model slate deposits", Eng. Geol., vol. 98 (2008), pp. 50-59. doi:10.1016/j.enggeo.2008.01.006

(16) Matías, J.; Vaamonde, A.; Taboada, J.; González-Manteiga, W.: "Support vector machines and gradient boosting for graphical estimation of a slate deposit", Stoch. Env. Res. Risk A., vol. 18, núm. 5 (2004), pp. 309-323.

(17) Taboada, J.; Ordóñez, C.; Saavedra, A.; Fiestras-Janeiro, G.: "Fuzzy expert system for economic zonation of an ornamental slate deposit", Eng. Geol., vol. 84 (2006), pp. 220-228. doi:10.1016/j.enggeo.2006.02.002

(18) Taboada, J.; Vaamonde, A.; Saavedra, A.; Arguelles, A.: "Quality index for ornamental slate deposits", Eng. Geol., vol. 50 (1998), pp. 203-210. doi:10.1016/S0013-7952(98)00019-2

(19) Taboada, J.; Matías, J. M.; Ordóñez, C.; García, P. J.: "Creating a quality map of a slate deposit using support vector machines", J. Comput. Appl. Math., vol. 204 (2007), pp. 84-94. doi:10.1016/j.cam.2006.04.030

(20) Rivas, T.; Matías, J. M.; Taboada, J.; Argüelles, A.: "Application of Bayesian networks to the evaluation of roofing slate quality", Eng. Geol., vol. 94 (2007), pp. 27-37. doi:10.1016/j.enggeo.2007.06.002

(21) Lotze, F.: "Zur Gliederung der Varisziden der Iberischen Meseta", Geotek. Forsch., vol. 6 (1945), pp. 78-92.

(22) Julivert, M.: "Decollement tectonics in the Hercynian Cordillera of Northwest Spain", Am. J. Sci., vol. 270-1 (1971), pp. 1-29.

(23) Farias, P.; Gallastegui, G.; González Lodeiro, F.; Marquínez, J. M.; Martín Parra, L. M.; Martínez Catalán, J. R.; De Pablo Macía, J.

G.; Rodríguez Fernández, L. R.: "Aportaciones al conocimiento de la litoestratigrafía y estructura de Galicia", IX Reunión de Geología del Oeste Peninsular, Oporto, Portugal (1985), pp. 411-431.

(24) Suárez, O.; Corretgé, L. G.; Martínez, F. J.: "West Asturian-Leonese Zone: Distribution and characteristics of the hercynian metamorphism", Premesozoic Geology of Iberia, RD. Dallmeyer \& E. Martínez-García eds., Springer-Verlag (1990), pp. 129-133.

(25) Marcos, A.: "Las series del Paleozoico inferior y la estructura herciniana del occidente de Asturias (NW de España)", Trab. Geol. Univ. Oviedo, vol. 6 (1973), pp. 3-113.

(26) Pérez Estaun, A.; Bastida, F.; Martínez Catalán, J. R.; Gutiérrez Marco, J. C.; Marcos, A.; Pulgar, J. A.: "West Asturian-Leonese Zone: Stratigraphy", Pre-Mesozoic Geology of Iberia, RD. Dallmeyer \& E. Martínez-García eds., Springer-Verlag (1990), pp. 92-102.

(27) Barros, J. C.: "New geological and cartographic data about the south limb of the Truchas Synclinorium (Ourense-León), NW Spain", Cuad. Lab. Xeol. Laxe, vol. 14 (1989), pp. 93-116.

(28) Pérez Estaun, A.: "Estratigrafía y estructura de la rama S. de la Zona Asturoccidental-leonesa", Mem. Inst. Geol. Min. España, vol. 92 (1978), pp. 1-151.

(29) Bastida, F.; Martínez Catalán, J. R.; Pulgar, J.: "Structural, metamorphic and magmatic history of the Mondoñedo Nappe (Hercynian Belt, NW Spain)", J. Struct. Geol., vol. 8 (1986), pp. 415-430. doi:10.1016/0191-8141(86)90060-X

(30) Martínez Catalán, J. R.; Pérez Estaun, A.; Bastida, F.; Pulgar, J.; Marcos, A.: "West Asturian-Leonese Zone: Structure", Pre-Mesozoic Geology of Iberia, RD. Dallmeyer \& E. Martínez-García eds., Springer-Verlag (1990), pp. 103-114.

(31) Martínez Catalán, J. R.; Hacar Rodríguez, M. P.; Villar Alonso, P.; Pérez Estaun, A.; González Lodeiro, F.: "Lower Palaeozoic extensional tectonics in the limit between the West Asturian-Leonese and Central Iberian Zones of the Variscan Fold Belt in NW Spain", Geol. Rund., vol. 81 (1992), pp. 545-560. doi:10.1007/BF01828614

(32) UNE-EN 12326-2:2000: Productos de pizarra y piedra natural para tejados inclinados y revestimientos. Parte 2: Métodos de ensayo. Asociación Española de Normalización y Certificación, p. 56.

(33) Bayliss, S. W.: "Nomenclature of the trioctahedral chlorites", Can. Mineral., vol. 13 (1975), pp. 178-180.

(34) Bard, J. P.: Microtextura de rocas magmáticas y metamórficas, p. 181, Mason, S. A., Barcelona (1989).

(35) Voll, G.: "New work on petrofabrics", Liverpool Manchester Geol., vol. 2 (1960), pp. 503-567.

(36) McKibben, M. A.; Barnes, H. L.: "Oxidation of pyrite in low temperature acidic solutions: Rate laws and surface textures", Geochim. Cosmochim. Acta, vol. 50, núm. 7 (1986), pp. 1509-1520.

(37) Nicholson, R. V.; Scharer, J. M.: "Laboratory studies of pyrrhotite oxidation kinetics", Environmental Geochemistry of Sulfide Oxidation, CN. Alpers \& D.W. Blowes, eds. ACS Symposium Series, Washington, DC, vol. 550 (1994), pp. 14-30.

(38) Rimstidt, J. D.; Chermak, J. A.; Gagen, P. M.: "Rates of reaction of galena, sphalerite, chalcopyrite and arsenopyrite with Fe (III) in acidic solutions", Environmental Geochemistry of Sulfide Oxidation, CN. Alpers \& D.W. Blowes, eds. ACS Symposium Series, Washington, DC, vol. 550 (1994), pp. 2-13.

(39) Janzen, M. P.; Nicholson, R. V.; Scharer, J. M.: "Pyrrhotite reaction kinetics: reaction rates for oxidation by oxygen, ferric iron, and for nonoxidative dissolution", Geochim. Cosmochim. Acta, vol. 64 (2000), pp. 1511-1522. doi:10.1016/S0016-7037(99)00421-4

(40) Morse, J. W.; Arvidson, R. S.: "The dissolution kinetics of major sedimentary carbonate minerals", Earth-Sci. Rev., vol. 58, núm. 12 (2002), pp. 51-84.

(41) Duckworth, O. W.; Martin, S. T.: "Role of molecular oxygen in the dissolution of siderite and rhodochrosite", Geochim. Cosmochim. Acta, vol. 68, núm. 3 (2004), pp. 607-621.

(42) García-Guinea, J.; Cárdenes, M.; Lombardero, M.; Desiloniz, M. I.: "Determination of iron sulphides in roofing slates from the north west of Spain", Mater. Construc., vol. 52, núm. 266 (2002), pp. 55-63. 